\title{
RELIABILITY ANALYSIS OF RHS STEEL TRUSSES JOINTS BASED ON THE P-BOXES APPROACH
}

\author{
Anastasia A. Soloveva, Sergey A. Solovev \\ Vologda State University, Vologda, Russia
}

\begin{abstract}
Reliability is one of the main indicators of structural elements mechanical safety. The choice of stochastic models is an important task in reliability analysis for describing the variability of random variables with aleatory and epistemic uncertainty. The article proposes a method for the reliability analysis of RHS (rectangular hollow sections) steel truss joints based on p-boxes approach. The p-boxes consist of two boundary distribution functions that create an area of possible distribution functions of a random variable. The using of p-boxes make possible to model random variables without making unreasonable assumptions about the exact cumulative distribution functions (CDF) or the exact values of the CDF parameters. The developed approach allows to give an interval estimate of the non-failure probability of the truss joints, which is necessary for a comprehensive (system) reliability analysis of the entire truss.
\end{abstract}

Keywords: reliability, truss, joint, p-box, random variable, safety, uncertainty, probabilistic design

\section{МЕТОД ОЦЕНКИ НАДЕЖНОСТИ УЗЛОВ СТАЛЬНЫХ ФЕРМ ИЗ ГНУТОСВАРНЫХ ПРОФИЛЕЙ (ГСП) НА ОСНОВЕ Р-БЛОКОВ}

\author{
А.А. Соловьева, С.А. Соловьев \\ Вологодский государственный университет, г. Вологда, РОССИЯ
}

\begin{abstract}
Аннотация: Надежность является одним из главных показателей механической безопасности элементов строительных конструкций. При вероятностной оценке надежности важной задачей является выбор стохастических моделей для описания изменчивости случайных величин с учетом алеаторной и эпистемологической неопределенности. В статье предложен метод расчета надежности узлов стальных ферм из гнутосварных профилей на основе р-блоков (p-boxes). Р-блоки состоят из двух граничных функций распределения, создающих область возможных функций распределения случайной величины. Использование р-блоков позволяет моделировать случайные величины без необоснованных предположений о точном вероятностном распределении или точных значениях параметров функций распределения вероятностей. Разработанный подход позволяет дать в интервальной форме оценку вероятности безотказной работы узла фермы, которая необходима для комплексной (системной) оценки надежности всей фермы.
\end{abstract}

Ключевые слова: надежность, ферма, узел, р-блок, случайная величина, безопасность, неопределенность, вероятностное проектирование 


\section{INTRODUCTION}

Ensuring safety and reliability is one of the key aims in the design and inspection of structural elements. Structural reliability analysis is a powerful tool for evaluating the structural safety level. As noted in Eurocode 0 "Basis of structural design", reliability is "an ability of a structure or a structural member to fulfil the specified requirements, including the design working life, for which it has been designed. Reliability is usually expressed in probabilistic terms, and it covers safety, serviceability and durability of a structure".

The paper [1] also notes that theory and methods for structural reliability have been developed substantially in the last few years and they are actually a useful tool for evaluating rationally the safety of complex structures or structures with unusual designs. Recent evolution allows to anticipate that their application will gradually increase, even in the case of common structures". The existence of the randomness in structural parameters and loads makes the reliability analysis essential to structural safety [2].

One of the main tasks in structural reliability analysis is the choice of accurate stochastic models for random variables, taking into account all statistical uncertainties. The article [3] notes, that structural reliability analysis requires addressing all sources of uncertainty. To design reliable structural products, different forms of uncertainty in engineering provide a challenge for reliability analysis and carry higher requirements on uncertainty analysis.

In accordance with [3, 4, etc.], there are two fundamentally distinct forms of uncertainty in the structural probabilistic design. The first is variability that arises from environmental stochasticity, inhomogeneity of materials, fluctuations in time, variation in space. Variability is sometimes called Type I uncertainty or aleatory uncertainty to emphasize its relation to the randomness in gambling and games of chance. It is also sometimes called irreducible uncertainty because, in principle, it cannot be reduced by further empirical study (although it may be better characterized). The second kind of uncertainty is the incertitude that comes from scientific ignorance, measurement uncertainty, censoring, or other lack of knowledge. This is sometimes called Type II uncertainty or epistemic uncertainty. In contrast with aleatory uncertainty, epistemic uncertainty is sometimes called reducible uncertainty because it can generally be reduced by additional empirical effort at least in principle.

There are different approaches in structural reliability analysis for uncertainty modeling. One of the most common approaches is p-box (probability box) approach $[4,5]$. P-boxes were introduced as interval-type bounds on cumulative distribution functions by Williamson and Downs [6] in 1990. In general, p-box is an area bounded by cumulative distribution functions which is covers the real cumulative distribution function (unknown due to the aleatory and epistemic uncertainties).

Trusses are the common part of many structures. The safety and reliability of whole building or structure depends from the trusses reliability. The complex truss reliability consist of truss elements (bars and joints) reliabilities. It is necessary to have the reliability values of the bars and joints of the truss for a comprehensive assessment of the entire truss reliability.

The article presents the approaches for RHS (rectangular hollow sections) steel trusses joints reliability analysis based on p-boxes for uncertainty modeling.

\section{METHODS}

Four limit state criteria for each joint element should be taken into account in reliability analysis of typical RHS truss: bearing capacity of the chord wall to which the brace element is adjacent (I); buckling of the chord side wall (II); bearing capacity of the brace element near the abutment to the chord (III); strength of welds (IV).

The Appendix L of SP 16.13330.2011 «Steel structures» presents the following inequality for 
bearing capacity of the chord wall to which the brace element is adjacent:

$$
\left(N+\frac{1.5 M}{d_{b}}\right) \frac{(0.4+1.8 g / b) \cdot f \cdot \sin \alpha}{\gamma_{c} \cdot \gamma_{d} \cdot \gamma_{D} \cdot R_{y} \cdot t^{2} \cdot(b+g+\sqrt{2 D f})} \leq 1,
$$

where $N$ is an initial force in a brace element; $M$ is a bending moment in a brace element; $R_{y}$ is a ultimate steel stress (design yield strength); is a force factor: $\gamma_{d}=1.0$ if a brace element is compressed, $\gamma_{d}=1.2$ if a brace element in tension; $\gamma_{c}$ is a factor of operation conditions; $\gamma_{D}$ is a factor of force influence in the chord; other parameters in (1) are shown on Fig. 1.

Bending moment $M$ occurs in most types of truss structures from the truss self-weight load and misalignments (eccentricities) of the truss member's connections. As the forces in the truss bars from the self-weight are a small variable value, the bending moment $M$ is considered as a deterministic (constant) value.

In case if the condition $\frac{F}{A \cdot R_{y}}>0.5$ met, then $\gamma_{D}=1.5-F /\left(R_{y} A\right)$ and the mathematical model of the limit state (1) based on SP 16.13330.2011 can be written as:

$$
\left(\widetilde{N}+\frac{1.5 M}{d_{b}}\right) \cdot k_{I}+\frac{\widetilde{F}}{A} \leq 1.5 R_{y},
$$

$$
\text { where } k^{I}=\frac{(0.4+1.8 g / b) \cdot f \cdot \sin \alpha}{\gamma_{c} \cdot \gamma_{d} \cdot t^{2} \cdot(b+g+\sqrt{2 D f})} \text {. }
$$

Wave line above the symbols is the indicator of random variables in mathematical models of limit states.

As the force in brace member $\widetilde{N}$ and in chord member $\widetilde{F}$ depends on the joint load $\widetilde{P}$ and the truss geometric parameters, then inequality (2) can be written as:

$$
\left(\delta_{N} \widetilde{P}+\frac{1.5 M}{d_{b}}\right) \cdot k_{I}+\frac{\delta_{F} \widetilde{P}}{A} \leq 1.5 R_{y},
$$

where $\delta_{N}$ and $\delta_{F}$ are factors for internal forces in truss bars depending on the truss geometric parameters. The inequality (2) can be converted to the next form:

$$
\widetilde{P} \leq P_{u l t}^{I},
$$

where $P_{u l t}^{I}=\left(1.5 R_{y}-\frac{1.5 M}{d_{b}} k_{I}\right) /\left(\delta_{N} \cdot k_{I}+\frac{\delta_{F}}{A}\right)$.

In other cases, the reliability analysis of the truss joints according to the criterion of the bearing capacity of the chord wall can be carried out using the mathematical model:

$$
\delta_{N} \widetilde{P} \leq \frac{R_{y}}{k_{I}}-\frac{1.5 M}{d_{b}} \text { or } \widetilde{P} \leq P_{u l t}^{I^{\prime}} \text {, }
$$

where $P_{u l t}^{I^{\prime}}=\frac{1}{\delta_{N}}\left(\frac{R_{y}}{k_{I}}-\frac{1.5 M}{d_{b}}\right)$.

The geometric parameters (Fig. 1) in the factor $k_{I}$, can be adopted as constant values on the structural design stage. After the construction of the truss structure, the reliability can be recalculated taking into account changes in the parameter $k_{I}$ by the actual values of geometric parameters after manufacturing and installation of the truss in site. The mathematical model for the truss's joint reliability analysis according to the buckling of the chord side wall criterion (II) can be written as:

$$
\widetilde{P} \leq P_{\text {ult }}^{I I},
$$

where $P_{u l t}^{I I}=\frac{1}{\delta_{N}}\left(\frac{2 \gamma_{c} \gamma_{t} k R_{y} t d_{b}}{\sin ^{2} \alpha}\right)$.

The mathematical model for the RHS truss's joint reliability analysis according to the criterion of bearing capacity of the brace element near the abutment to the chord (III) can be written as:

$$
\widetilde{P} \leq P_{u l t}^{I I I},
$$

where $P_{u l t}^{I I I}=\frac{1}{\delta_{N}}\left[\frac{\gamma_{c} \cdot \gamma_{d} \cdot k \cdot R_{y d} \cdot A_{d}}{(1.4+0.018 D / t) \cdot \sin \alpha}-\frac{M}{2 d_{b}}\right]$. 
And, the mathematical model for the RHS truss's joint reliability analysis according to the criterion of strength of welds (IV) is:

$$
\widetilde{P} \leq P_{\text {ult }}^{I V},
$$

where

$$
P_{\text {ult }}^{I V}=\frac{1}{\delta_{N}}\left(\frac{4 \cdot \beta_{f} \cdot k_{f} \cdot d_{b} \cdot \gamma_{c} \cdot R_{w f}}{\left[1+0.01\left(3+\frac{5 d}{D}-\frac{0.1 d_{b}}{t_{d}}\right) \frac{D}{t}\right] \cdot \sin \alpha}-\frac{M}{2 d_{b}}\right),
$$

$R_{w f}$ is a design resistance of the welding corner seams to the shear; $k_{f}$ is a leg of a fillet weld; $\beta_{f}$ is a fillet weld factor.

The design mathematical models (4)-(8) contain joint loads of $P$ (Fig. 1). To account for deterministic non-joint loads (self-weight and bracing/purlin weight), an equivalent joint load $P^{e q}$ is selected, which creates similar forces $F$ and $N$ in the truss elements.

There are possible some different limit state equations. For example, "Design guide for rectangular hollow section (RHS) joints under predominantly static loading" [7] proposed 5 limit state criterion: chord face plastification, local yielding of brace, chord punching shear, chord shear, chord side wall failure. In general, there are the same shape of presented in [7] equations and equations (4)-(8). A similar observation is true for the equations in the paper [8]. The reliability analysis approach presented below can be easily adapted to the design equations in $[7,8$, etc. $]$.

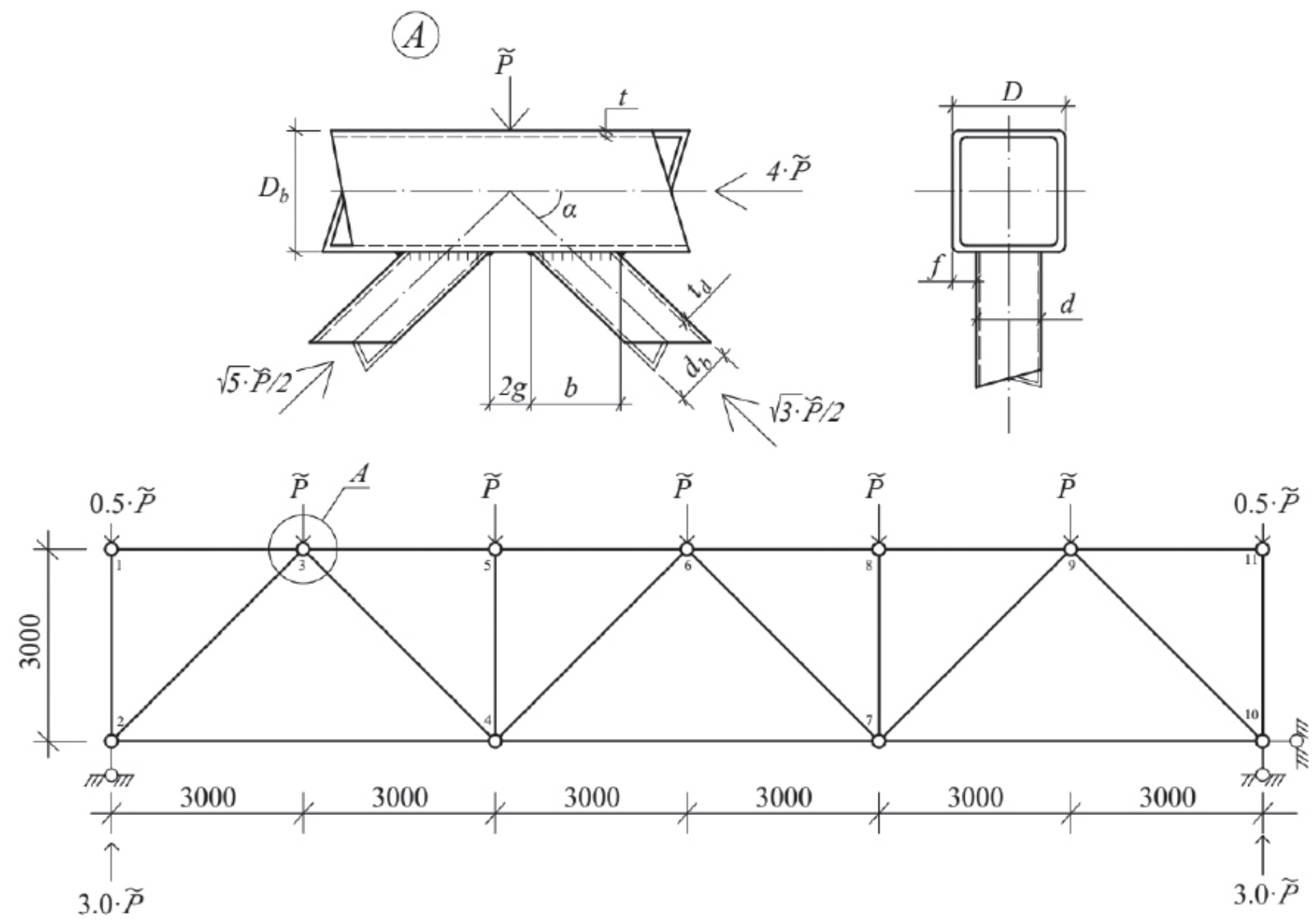

Figure 1. Design scheme of truss and joint No. 3 Figure 1. Design scheme of truss and joint No. 3 


\section{RESULTS AND DISCUSSION}

Table 1 presents the forces in the truss (Fig. 1) bars. As noted above, there are different p-box models for random variables depending on quantity and quality of statistical data. For example, if the cumulative distribution function of a random variable is known - normal distribution, but there are interval estimations of expected value $m_{X} \in\left[\underline{m}_{X} ; \bar{m}_{X}\right]$ and standard deviation $S_{X} \in\left[\underline{S}_{X} ; \bar{S}_{X}\right]$, the following boundary distribution functions can be used for the p-box model:

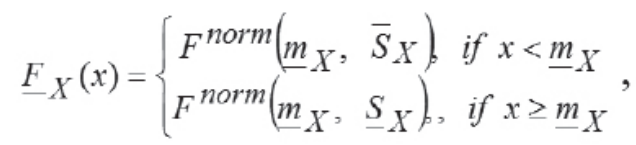

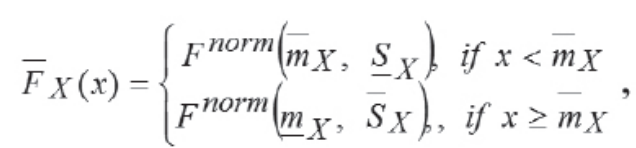

where $F^{\text {norm }}()$ is a cumulative distribution function of normal distribution.

If there are extremely small statistical data about random variable, the fuzzy distribution functions can be used [9]:

$$
\bar{F}_{X}(x)=\left\{\begin{array}{c}
1-\exp \left[-\left(\frac{x-a_{X}}{b_{X}}\right)^{2}\right] \text { if } x>a_{X} \\
0 \text { otherwise }
\end{array}\right.
$$

$$
\underline{F}_{X}(x)=\left\{\begin{array}{c}
\exp \left[-\left(\frac{x-a_{X}}{b_{X}}\right)^{2}\right] \text { if } x<a_{X}, \\
1 \text { otherwise }
\end{array}\right.
$$

where $a_{X}$ is a "mean" value which is calculated as $a_{X}=0.5\left(X_{\max }+X_{\min }\right) ; b_{X}$ is a measure of variance which is calculated as $b_{X}=0.5\left(X_{\max }-X_{\min }\right) / \sqrt{-\ln \alpha}$, where $X_{\max }$ and $X_{\min }$ is a maximum and a minimum value in the set of $\{X\} ; \alpha$ is a cut (risk) level [9]. The Gumbel distribution (or Generalized Extreme Value distribution Type-I) is often used for stochastiseveral $\mathrm{c}$ modeling of the snow load $[10,11]$. If there is uncertainty in estimation of snow load statistical parameters $m_{X} \in\left[\underline{m}_{X} ; \bar{m}_{X}\right]$ and $S_{X} \in\left[\underline{S}_{X} ; \bar{S}_{X}\right]$, the following boundary distribution functions (p-box model) can be used:

$$
\begin{aligned}
& \underline{F}_{X}(x)=\left\{\begin{array}{l}
\exp \left[-\exp \left(\frac{\left[\underline{m}_{X}-0.45 \cdot \bar{S}_{X}\right]-x}{0.78 \cdot \bar{S}_{X}}\right)\right] \text { if } x<\underline{m}_{X} \\
\exp \left[-\exp \left(\frac{\left[\underline{m}_{X}-0.45 \cdot \underline{S}_{X}\right]-x}{0.78 \cdot \underline{S}_{X}}\right)\right] \text { if } x \geq \underline{m}_{X}
\end{array}\right. \\
& \bar{F}_{X}(x)=\left\{\begin{array}{l}
\exp \left[-\exp \left(\frac{\left[\bar{m}_{X}-0.45 \cdot \underline{S}_{X}\right]-x}{0.78 \cdot \underline{S}_{X}}\right)\right] \text { if } x<\bar{m}_{X} \\
\exp \left[-\exp \left(\left[\frac{\left.\bar{m}_{X}-0.45 \cdot \bar{S}_{X}\right]-x}{0.78 \cdot \bar{S}_{X}}\right)\right] \text { if } x \geq \bar{m}_{X}\right.
\end{array}\right.
\end{aligned}
$$

Table 1. Forces in the truss (Fig. 1) bars

\begin{tabular}{|c|c|c|c|c|c|}
\hline Bar & Force & $\delta_{N}$ & Bar & Force & $\delta_{N}$ \\
\hline $1-2,10-11$ & $-0,5 \widetilde{P}$ & -0.5 & $4-5,7-8$ & $-\widetilde{P}$ & -1 \\
\hline $1-3,9-11$ & 0 & 0 & $4-6,6-7$ & $-\widetilde{P} / \sqrt{2}$ & $-1 / \sqrt{2}$ \\
\hline $2-3,9-10$ & $-\sqrt{5} \widetilde{P} / 2$ & $-\sqrt{5} / 2$ & $4-7$ & $+4.5 \cdot \widetilde{P}$ & +4.5 \\
\hline $2-4,7-10$ & $+2.5 \widetilde{P}$ & +2.5 & $3-4,7-9$ & $+\sqrt{3} \widetilde{P} / 2$ & $+\sqrt{3} / 2$ \\
\hline $\begin{array}{c}3-5,8-9,5-6, \\
6-8\end{array}$ & $-4 \widetilde{P}$ & -4 & \multicolumn{3}{|l}{} \\
\hline
\end{tabular}


Table 2. Statistical data about loads on the truss

\begin{tabular}{|c|c|c|c|c|}
\hline No. & Joint load & Distribution & $\begin{array}{c}\text { Expected value of } \\
\text { force } P, \mathrm{kN}\end{array}$ & $\begin{array}{c}\text { Deviation of force } \\
P, \mathrm{kN}\end{array}$ \\
\hline 1 & $\begin{array}{c}\text { Load from the truss self- } \\
\text { weight and weight of the } \\
\text { braces }\left(P^{e q}\right)\end{array}$ & Constant value & 4.5 & - \\
\hline 2 & $\begin{array}{c}\text { Ribbed reinforced concrete } \\
\text { slabs weight }\end{array}$ & Normal, (9)-(10) & {$[70.0 ; 73.0]$} & {$[1.0 ; 3.0]$} \\
\hline 3 & Structural insulation weight & Fuzzy, (11)-(12) & $a_{x}=45.0$ & $b_{x}=2.6$ \\
\hline 4 & Roof membrane weight & Normal, (9)-(10) & {$[2.5 ; 3.0]$} & 0.3 \\
\hline 5 & Snow load & Gumbel $[10]$ & $\alpha \in[\underline{\alpha} ; \bar{\alpha}]=[35.0 ; 40.0]$ & $\beta \in[\underline{\beta} ; \bar{\beta}]=[8.0 ; 12.0]$ \\
\hline
\end{tabular}

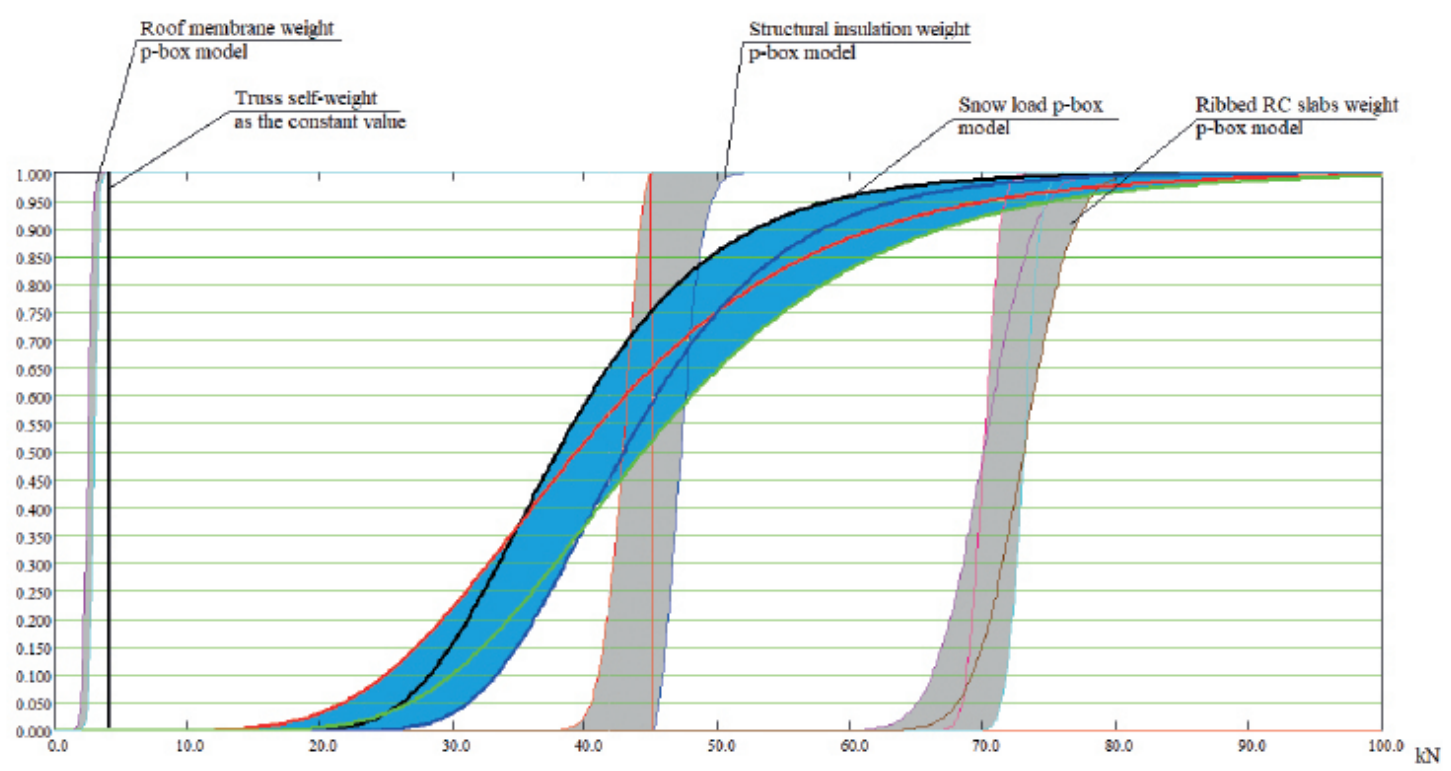

Figure 2. P-boxes plots of truss loads by the Table 2

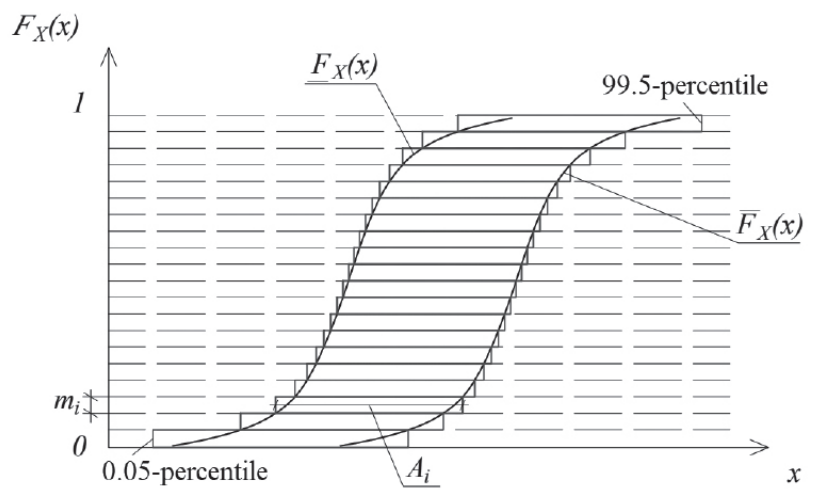

Figure 3. P-box discretization on focal elements $A_{i}$ with basic probabilities $m i$
Interval estimates for statistical parameters are refined for snow regions or individual localities depending on the available statistical sample of weather station data on yearly snow cover height maxima (or the snow weight directly).

Fig. 2 presents the p-boxes plots of joint loads by statistical data of the Table 2 . There is a problem of different type p-boxes addiction for stochastic estimation of the total load.

For p-boxes addiction, it is necessary to transform it into a Dempster-Shafer type structure [4]. Continuous boundary cumulative distribution functions in p-boxes are sampled into a certain number of blocks (Fig. 3). The distributions 
during discretization are limited to 0.05 and 99.5 percentiles [4].

The basic probability (discretization level) $m_{i}$ is usually takes as $m_{i}=0.01[4]$, and $\sum_{i=1}^{n} m_{i}=1$.

In such case, we get 100 interval estimations $A_{i}$ of random variable $X$ (Fig. 3). For example, one hundred intervals can be obtained by discretization the p-box of the joint load from the snow weight: $\left[\underline{P}_{1}^{\text {snow }} ; \bar{P}_{1}^{\text {snow }}\right]$, $\left[\underline{P}_{2}^{\text {snow }} ; \bar{P}_{2}^{\text {snow }}\right], \ldots\left[\underline{P}_{100}^{\text {snow }} ; \bar{P}_{100}^{\text {snow }}\right]$. Similarly, one hundred intervals can be obtained for joint loads, for example, joint load form reinforced concrete slabs weight: $\left[\underline{P}_{1}^{r} ; \bar{P}_{1}^{r}\right],\left[\underline{P}_{2}^{r} ; \bar{P}_{2}^{r}\right], \ldots$ $\left[\underline{P}_{100}^{r} ; \bar{P}_{100}^{r}\right]$.

After p-boxes discretization, it is possible to summarize the p-boxes $[4,6]$ from different joint loads to the one common p-box. The table form (Table 1) is useful for two p-boxes addiction. Boundary distribution functions of p-boxes after discretization are can be presented as Dempster-Shafer [12] structures. Detailed information on mathematical operations with Dempster-Shafer structures is given in the research [4].

Table 3. Addiction of two Dempster-Shafer structures [4]

\begin{tabular}{|c|c|c|c|c|}
\hline & {$\left[\underline{P}_{1}^{\text {snow }} ; \bar{P}_{1}^{\text {snow }}\right], 0.01$} & $\left.\underline{P}_{2}^{\text {snow }} ; \bar{P}_{2}^{\text {snow }}\right], 0.01$ & $\cdots$ & $\left.\underline{P}_{100}^{\text {snow }} ; \bar{P}_{100}^{\text {snow }}\right], 0.01$ \\
\hline $\begin{array}{c}{\left[\underline{P}_{1}^{r} ; \bar{P}_{1}^{r}\right]} \\
0.01\end{array}$ & $\begin{array}{c}{\left[\underline{P}_{1}^{\text {snow }}+\underline{P}_{1}^{r} ; \bar{P}_{1}^{\text {snow }}+\bar{P}_{1}^{r}\right]} \\
0.0001\end{array}$ & $\begin{array}{c}{\left[\underline{P}_{2}^{\text {snow }}+\underline{P}_{1}^{r} ; \bar{P}_{2}^{\text {snow }}+\bar{P}_{1}^{r}\right]} \\
0.0001\end{array}$ & $\cdots$ & $\begin{array}{c}{\left[\underline{P}_{100}^{\text {snow }}+\underline{P}_{1}^{r} ; \bar{P}_{100}^{\text {snow }}+\bar{P}_{1}^{r}\right]} \\
0.0001\end{array}$ \\
\hline $\begin{array}{c}{\left[\begin{array}{cc}\underline{P}_{2}^{r} ; & \bar{P}_{2}^{r}\end{array}\right],} \\
0.01\end{array}$ & $\begin{array}{c}{\left[\underline{P}_{1}^{\text {snow }}+\underline{P}_{2}^{r} ; \bar{P}_{1}^{\text {snow }}+\bar{P}_{2}^{r}\right]} \\
0.0001\end{array}$ & $\begin{array}{c}\underline{P}_{2}^{\text {snow }}+\underline{P}_{2}^{r} ; \bar{P}_{2}^{\text {snow }}+\bar{P}_{2}^{r} \\
0.0001\end{array}$ & $\cdots$ & $\begin{array}{c}{\left[\underline{P}_{100}^{\text {snow }}+\underline{P}_{2}^{r} ; \bar{P}_{100}^{\text {snow }}+\bar{P}_{2}^{r}\right]} \\
0.0001\end{array}$ \\
\hline$\ldots$ & $\ldots$ & $\ldots$ & $\ldots$ & $\ldots$ \\
\hline $\begin{array}{c}{\left[\underline{P}_{100}^{r} ; \bar{P}_{100}^{r}\right.} \\
, 0.01\end{array}$ & $\begin{array}{c}{\left[\underline{P}_{1}^{\text {snow }}+\underline{P}_{100}^{r} ; \bar{P}_{1}^{\text {snow }}+\bar{P}_{100}^{r}\right]} \\
, 0.0001\end{array}$ & $\begin{array}{c}{\left[\underline{P}_{2}^{\text {snow }}+\underline{P}_{100}^{r} ; \bar{P}_{2}^{\text {snow }}+\bar{P}_{100}^{r}\right]} \\
0.0001\end{array}$ & $\ldots$ & $\begin{array}{c}{\left[\underline{P}_{100}^{\text {snow }}+\underline{P}_{100}^{r} ; \bar{P}_{100}^{\text {snow }}+\bar{P}_{100}^{r}\right.} \\
, 0.0001\end{array}$ \\
\hline
\end{tabular}

The elements in Table 1 are written as follows $A_{i} \in\left[\underline{P}_{i} ; \bar{P}_{i}\right], m_{i}$, where $\underline{P}_{i} ; \bar{P}_{i}$ are lower and upper bounds of the focal element $A_{i}, m_{i}$ is a basic probability for the focal element $A_{i}$.

The lower and upper boundary distribution functions can be constructed from these intervals based on the provisions of the DempsterShafer evidence theory $[4,12]$. These boundary distribution functions will create a p-box of joint load $P$. For more than two p-boxes, a combination of the sums of all dispatching options is considered. Information about automating the interval calculation process can be found in [4].
The p-box (Fig. 4) can be obtained by addiction of p-boxes and constant value of different joint loads in the Table 2. Such p-box is presented as empirical boundary distribution functions $\underline{F}_{P}(P)$ and $\bar{F}_{P}(P)$ consisting of possible combinations of different joint loads. The probability of non-failure can be calculated as:

$$
\begin{aligned}
& \underline{P}=\operatorname{Pr}\left(\tilde{P} \leq P_{u l t}\right)=\underline{F}_{P}\left(P_{u l t}\right), \\
& \bar{P}=\operatorname{Pr}\left(\widetilde{P} \leq P_{u l t}\right)=\bar{F} P\left(P_{u l t}\right) .
\end{aligned}
$$

For example (Fig, 4), the non-failure probability interval for truss bar $2-3$ in joint 3 by the 
bearing capacity of the brace element near the $\quad \bar{P}_{2-3}^{I I I}=\bar{F}_{P}\left(P_{\text {ult }}^{I I I}\right)$. The reliability is presented in abutment to the chord is $\underline{P}_{2-3}^{I I I}=\underline{F}_{P}\left(P_{u l t}^{I I I}\right)$, interval form $\left[\underline{P}_{2-3}^{I I I} ; \bar{P}_{2-3}^{I I I}\right]$.

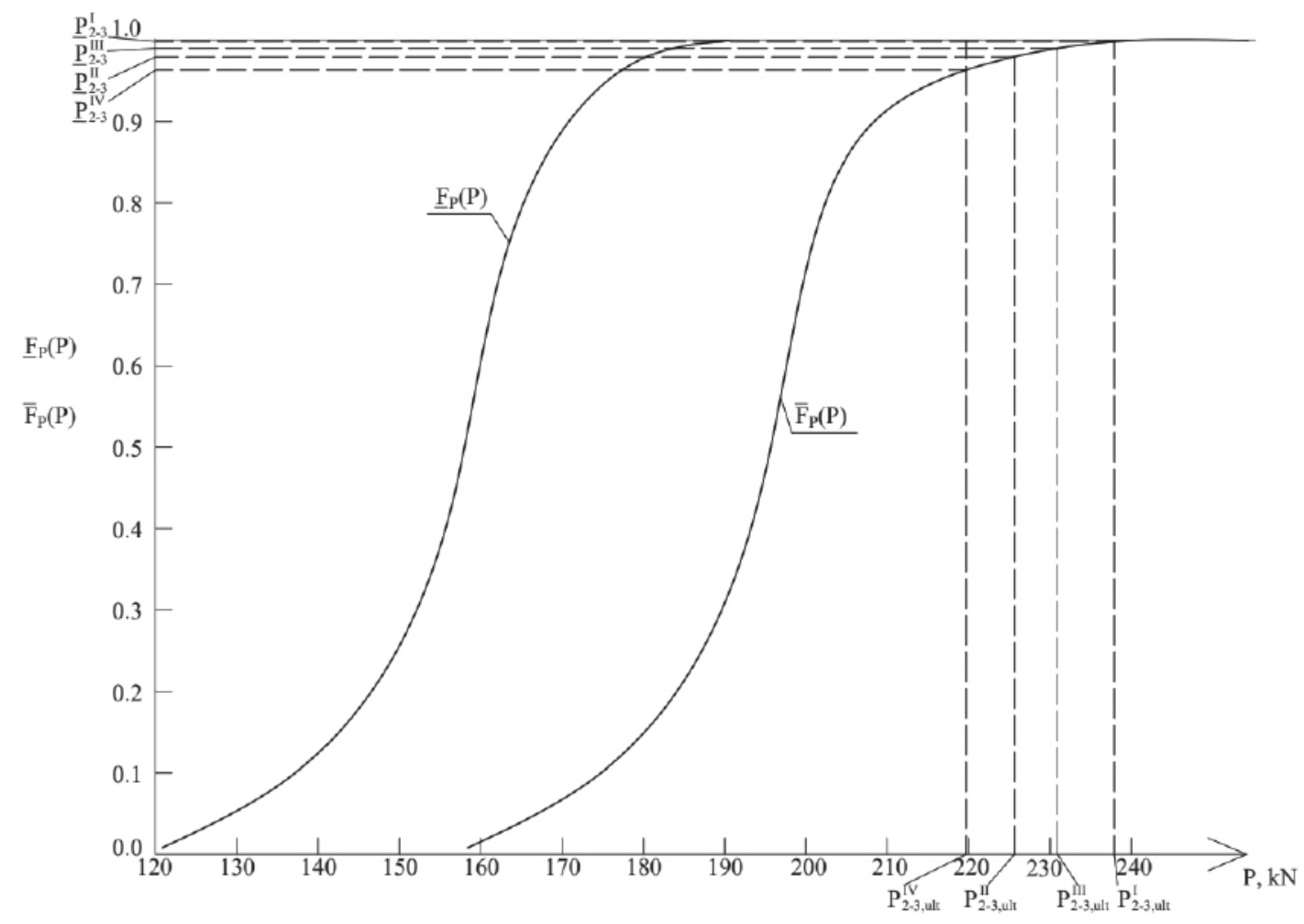

Figure 4. The p-box obtained by addiction of the b-boxes in the Table 2

There will be several reliability intervals for every truss joints $\left[\underline{P}_{i-j}^{z} ; \bar{P}_{i-j}^{z}\right]$, where $z$ is an indicator of limit state criterion, $i-j$ is an indicator of truss bar.

A comprehensive assessment of the reliability of the selected truss joint can be obtained from a given subset of intervals $\left[\underline{P}_{i-j}^{z} ; \bar{P}_{i-j}^{z}\right]$ using the following equations [13]:

$$
\left\{\begin{array}{c}
\underline{P}=\max \left(0, \sum_{i-j}^{n} \underline{P}_{i-j}^{z}-(n-1)\right), z=\{I, I I, I I I, I V\}, \\
\bar{P}=\min \left(\bar{P}_{i-j}^{z}\right)
\end{array}\right.
$$

where $\mathrm{n}$ is a number of brace elements in the truss joint.
The advantage of using mathematical models (4)-(8) is that it simple to use different limit state models $[7,8$, etc. $]$ in presented algorithm replacing $P_{u l t}$.

The mathematical models (4)-(8) can be presented for existing steel trusses as:

$$
\widetilde{P} \leq \widetilde{P}_{u l t}\left(\widetilde{\sigma}_{S, u l t}\right)
$$

where $\widetilde{\sigma}_{s, u l t}$ is an steel ultimate stress obtained by the steel samples tests results.

Such models can be used in cases when there is no information about steel of existing truss or at degradation of physical and mechanical properties of structural steel. Algorithms for analyzing the reliability of truss joints can be taken from paper [14] in such design situations. 
Values of truss joints reliability can be used in structural reliability analysis of truss as a mechanical system or in decision making and risk analysis problems $[15,16]$.

\section{CONCLUSIONS}

1. The p-boxes can be used for more careful modeling of random variables in the structural reliability analysis problems;

2. If the reliability interval $[P ; \bar{P}]$ is too wide for decision making, it is necessary to obtain narrower boundary distribution functions by increasing the quantity or quality of statistical data about random variables;

3 . The proposed reliability analysis method for HSS truss joints can be used in truss reliability analysis as a structural system.

\section{REFERENCES}

1. Cardoso J.B., de Almedia J.R., Dias J.M., Coelho P.G. Structural reliability analysis using Monte Carlo simulation and neural networks. Advances in Engineering Software. 2008. Vol. 39. No. 6. Pp. 505-513.

2. Yi J., Wu F., Zhou Q., Cheng Y., Ling H., Liu J. An active-learning method based on multi-fidelity Kriging model for structural reliability analysis. Structural and Multidisciplinary Optimization. 2021. Vol. 63(1). Pp. 173-195.

3. Lingfei Y.O.U., Zhang J., Xiaosong D.U., Jie W.U. A new structural reliability analysis method in presence of mixed uncertainty variables. Chinese Journal of Aeronautics. 2020. Vol. 33(6). Pp. 1673-1682.

4. Ferson S., Kreinovich V., Grinzburg L., Myers D., Sentz K. Constructing probability boxes and Dempster-Shafer structures. Sandia National Lab. Albuquerque. 2015. $132 \mathrm{p}$.

5. Liu X., Wang X., Xie J., Li B. Construction of probability box model based on maximum entropy principle and corresponding hybrid reliability analysis approach. Structural and Multidisciplinary Optimization. 2020. Vol. 61(2). Pp. 599-617.

6. Williamson R.C., Downs T. Probabilistic arithmetic I: numerical methods for calculating convolutions and dependency bounds. International Journal of Approximate Reasoning. 1990. Vol. 4. Pp. 89-158.

7. Packer J.A., Wardenier J., Zhao X.L., van der Vegte G.J., Kurobane Y. Design guide for rectangular hollow section (RHS) joints under predominantly static loading. CIDECT. 2009. 149 p.

8. Bródka J., Broniewicz M. Design of trusses made of channel sections according to Eurocode rules. Journal of Civil Engineering, Environment and Architecture. JCEEA. 2015. Vol. 32. No. 62. Pp. 1-26.

9. Zhang M., Yang Y., Wang H., Wang L. Study of cut-set distributions in the fuzzy reliability evaluation models. Applied Mathematical Modelling. 2020. Vol. 88. Pp. 142-160.

10. Zolina T.V., Sadchikov P.N. Modelirovanie snegovoy nagruzki na pokrytie promyshlennogo zdaniya [Modeling of the Snow Load on the Roofs of Industrial Buildings]. Vestnik MGSU [Proceedings of Moscow State University of Civil Engineering]. 2016. No. 8. Pp. 25-33. (in Russian)

11. Wolinski S., Pytlowany T. Evaluation of load values using the Gumbel model. Archives of Civil Engineering. 2012. Vol. 58(2). Pp. 199-208.

12. Zhang Z., Jiang C., Wang G.G., Han $X$. First and second order approximate reliability analysis methods using evidence theory. Reliability Engineering \& System Safety. 2015. Vol. 137. Pp. 40-49.

13. Gurov S.V., Utkin L.V. Nadezhnost' sistem pri nepolnoj informacii [Reliability of systems with limited information]. SaintPetersburg, Lyubovich, 1999. 166 p. (in Russian) 
14. Solov'ev S.A. Analiz nadezhnosti elementov stroitel'nyh konstrukcij na osnove kombinacii teorii sluchajnyh mnozhestv i veroyatnostnyh raspredelenij [Structural elements reliability analysis based on random set theory and probability distributions combination]. Stroitel'naya mekhanika i raschet sooruzhenij [Structural Mechanics and Analysis of Constructions]. 2020. No. 2 (289). Pp. 61-66. (in Russian)

15. Leimeister M., Kolios A. A review of reliability-based methods for risk analysis and their application in the offshore wind industry. Renewable and Sustainable Energy Reviews. 2018. Vol. 91. Pp. 1065-1076.

16. Trbojevic V.M. Another look at risk and structural reliability criteria. Structural Safety. 2009. Vol. 31(3). Pp. 245-250.

\section{СПИСОК ЛИТЕРАТУРЫ}

1. Cardoso J.B., de Almedia J.R., Dias J.M., Coelho P.G. Structural reliability analysis using Monte Carlo simulation and neural networks. Advances in Engineering Software. 2008. Vol. 39. No. 6. Pp. 505-513.

2. Yi J., Wu F., Zhou Q., Cheng Y., Ling H., Liu J. An active-learning method based on multi-fidelity Kriging model for structural reliability analysis. Structural and Multidisciplinary Optimization. 2021. Vol. 63(1). Pp. 173-195.

3. Lingfei Y.O.U., Zhang J., Xiaosong D. U., Jie W.U. A new structural reliability analysis method in presence of mixed uncertainty variables. Chinese Journal of Aeronautics. 2020. Vol. 33(6). Pp. 1673-1682.

4. Ferson S., Kreinovich V., Grinzburg L., Myers D., Sentz K. Constructing probability boxes and Dempster-Shafer structures. Sandia National Lab. Albuquerque. 2015. $132 \mathrm{p}$.

5. Liu X., Wang X., Xie J., Li B. Construction of probability box model based on maximum entropy principle and corresponding hybrid reliability analysis approach. Structural and Multidisciplinary Optimization. 2020. Vol. 61(2). Pp. 599-617.

6. Williamson R.C., Downs T. Probabilistic arithmetic I: numerical methods for calculating convolutions and dependency bounds. International Journal of Approximate Reasoning. 1990. Vol. 4. Pp. 89-158.

7. Packer J.A., Wardenier J., Zhao X.L., van der Vegte G.J., Kurobane Y. Design guide for rectangular hollow section (RHS) joints under predominantly static loading. CIDECT. 2009. 149 p.

8. Bródka J., Broniewicz M. Design of trusses made of channel sections according to Eurocode rules. Journal of Civil Engineering, Environment and Architecture. JCEEA. 2015. Vol. 32. No. 62. Pp. 1-26.

9. Zhang M., Yang Y., Wang H., Wang L. Study of cut-set distributions in the fuzzy reliability evaluation models. Applied Mathematical Modelling. 2020. Vol. 88. Pp. 142-160.

10. Золина Т.В., Садчиков П.Н. Моделирование снеговой нагрузки на покрытие промышленного здания // Вестник МГСУ. 2016. № 8. C. 25-33.

11. Wolinski S., Pytlowany T. Evaluation of load values using the Gumbel model. Archives of Civil Engineering. 2012. Vol. 58(2). Pp. 199-208.

12. Zhang Z., Jiang C., Wang G. G., Han $\mathbf{X}$. First and second order approximate reliability analysis methods using evidence theory. Reliability Engineering \& System Safety. 2015. Vol. 137. Pp. 40-49.

13. Гуров С.В., Уткин Л.В. Надежность систем при неполной информации. СПб: Любович, 1999. 166 с.

14. Соловьев С.А. Анализ надежности элементов строительных конструкций на основе комбинации теории случайных множеств и вероятностных распределений // Строительная механика и расчет сооружений. 2020. № 2 (289). C. 61-66. 
15. Leimeister M., Kolios A. A review of reliability-based methods for risk analysis and their application in the offshore wind industry. Renewable and Sustainable Energy Reviews. 2018. Vol. 91. Pp. 1065-1076.
16. Trbojevic V.M. Another look at risk and structural reliability criteria. Structural Safety. 2009. Vol. 31(3). Pp. 245-250.
Anastasia A. Soloveva, post-graduate student, Vologda State University, Department of Industrial and Civil Engineering; 160000, Russia, Vologda, Lenin str., 15; tel. 8(8172)53-3531, e-mail: solovevaaa@vogu35.ru

Sergey A. Solovev, associate professor, Vologda State University, Department of Industrial and Civil Engineering; 160000, Russia, Vologda, Lenin str., 15; tel. 8(8172)53-3531, e-mail: solovevsa@vogu35.ru
Соловьев Сергей Александрович, к.т.н., доцент кафедры промышленного и гражданского строительства, Вологодский государственный университет; 160000, Россия, г. Вологда, ул. Ленина, д. 15; тел. 8(8172)53-35-31, e-mail: solovevsa@vogu35.ru

Соловьева Анастасия Андреевна, аспирант, ФГБОУ ВО Вологодский государственный университет, кафедра промышленного и гражданского строительства; 160000 , Россия, г. Вологда, ул. Ленина, д. 15; тел. 8(8172)53-3531, e-mail: solovevaaa@vogu35.ru 